\begin{tabular}{|c|c|c|}
\hline $\bar{J}$ & $\begin{array}{c}\text { International Journal of Current Research } \\
\text { and Academic Review }\end{array}$ & 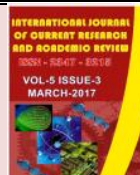 \\
\hline \begin{tabular}{|l|l|} 
EXCELLENT \\
PUBLISHERS
\end{tabular} & $\begin{array}{c}\text { ISSN: 2347-3215 (Online)', Volume 5, Number } 3 \text { (March-2017) } \\
\text { Journal homepage: http://www.ijcrar.com }\end{array}$ & \\
\hline
\end{tabular}

doi: https://doi.org/10.20546/ijcrar.2017.503.007

\title{
A Review on Monitoring Water Quality in Dal Lake
}

\author{
Shariqa Maryam* \\ P.G. Dept. of Environmental Science, S.P. College, Srinagar, Kashmir, India-190001 \\ *Corresponding author
}

\begin{abstract}
Water is essence of life on earth, being a finite resource it generates concern due to environmental issues related to its degradations. Lentic water resources are important natural aquatic ecosystems catering to various ecosystem services. Lakes are easily impacted by complex land-water relationships and human inputs of nutrients leading to significant decline in their recreational, aesthetic and aquatic ecosystem functions. The water quality can be assessed by monitoring the physico-chemical characteristics and the proliferation of planktons and aquatic plants. This paper highlights the ecological studies conducted on Dal lake.
\end{abstract}

\section{Article Info}

Accepted: 28 February 2017

Available Online: 20 March 2017

\section{Keywords}

Ecology, Lake,

Physico-chemical

properties.

\section{Introduction}

The earliest records on the ecological features of Dal Lake are that of Edmonson and Hutchinson (1939) who reported $\mathrm{pH}$ values for Dal waters between 8.2 and 8.5. on the Nigeen Lake the earliest studies is on lake sediments by De. Terra and Paterson (1939) who reported the average depth of the Nigeen Lake $5.2 \mathrm{~m}$ and the distribution of detritus and mineral grain in the lake sediment as: Coarse detritus $=23 \%$, fine detritus $=56 \%$ and mineral grain $=10 \%$.

Zutshi (1968) carried out detailed analysis of open waters of Dal Lake. On the basis of mean values it was established that the $\mathrm{pH}$ was on alkaline side throughout the year with marked seasonal variations depending upon the extent of photosynthesis. The values for dissolved oxygen for surface water were well below the saturation level during summer-autumn period. In Nigeen low oxygen content was recorded in deep waters during summer stratification. The levels of sp. Conductivity and alkalinity have been found to be moderate. Divalent cations were higher than monovalents.

The ecological studies on Dal Lake were scanty and isolated till 1970 and it was after that a spurt in publications was witnessed dealing with various aspects of the Dal Lake ecology (Kundangar et al., 2004). Kundangar (1973) provided limnological data on Dal and Nigeen lake while Zutshi and Vaas (1973) demonstrated the changing trophic status of Dal and Anchar lake. The same authors in the same year recorded progressive increase in COD of Dal Lake waters from 1965 to 1969. During 1965 the range was $0.7-4.0 \mathrm{mgl}^{-1}$ with a mean value of $2.3 \mathrm{mgl}^{-1}$ and after lapse of five years COD had increased to $2.5-22 \mathrm{mgl}^{-1}$ with a mean value of $12.2 \mathrm{mgl}-^{1}$

Kant and Kachroo (1977) while studying the hydrobiological features; composition and periodicity of phytoplankton in the Dal and Nigeen Lake provided the seasonal dynamics of phytoplankton along with diurnal changes in temperature, $\mathrm{pH}$ of water and movement of 
phytoplankton. Zutshi and Khan (1978) classified Kashmir Himalayan lakes based on multiple criteria into valley, forest, mountain types. The valley lakes were divided into drainage, semi-drainage and non-drainage sub-types. This system of typology provided a fairly good idea about the general limnological conditions of the lakes.

Enex (1978) a consultant agency of New Zealand while preparing a report for the Common wealth fund for technical cooperation on the study of pollution of Dal Lake reported a net flow of 5.5 tonnes of phosphorus and 88.9 tonnes of nitrogen drained every year from the surrounding settlements, hotels, the Dal Lake. Vass and Zutshi (1979) while studying the limnological studies on Dal lake reported appreciable water level fluctuations in the lake as a result of varied amount of precipitation received in form of rain and snow and the changes in the quality of water that flows into the lake from the feeding channels.

Kaul et al., (1980) while studying the mineral removal potential of some macrophytes in two lakes of Kashmir reported that the macrophyte growing in eutrophic lakes are more efficient in removal of $\mathrm{N}, \mathrm{Ca}$ and $\mathrm{K}$ compared with $\mathrm{P}$ and $\mathrm{Na}$ from the nutrient pool. Vass and Zutshi (1983) while calculating the heat budgets in various basins of Dal Lake reported the maximum heat storage for all basins during July and that of Nigeen 428 cal. According to authors the heat budget for Nigeen basin remained constant for the month of June, July and August and thereafter the basin lost the stored heat.

Urfi (1985) also repoted differential pollution of Dal lake with areas close to human settlements at a much higher levels of enrichment. At some inshore sites conductivity was observed to be $1258 \mu \mathrm{s}, \mathrm{po} 4=704 \mu \mathrm{g} / \mathrm{l}$ and nitrate $=1461 \mu \mathrm{g} / \mathrm{l}$. Trisal (1987) while presenting the data on physico chemical characteristics of Dal and Nigeen lake discussed the ecology and conservation of Dal lake in detail.

Kango et al., (1987) while using X-ray diffraction (XRD) and differential thermal analysis (DTA) to investigate clay mineral content of lake sediment reported the illite and chlorite being the main mine types in Dal lake.

Kachroo and Suri (1987) while summing up a decade of pollution in Dal Lake reported $77.1 \%$ decrease in transparency during 1976 and $70.3 \%$ during 1983, besides other chemical parameters. The authors revealed the relative abundance of some of the pollution indicator species which had increased during 1974-1985.

Zutshi and Wanganeo (1988) attempted for a nutrient load model to evaluate the trophic status of some Kashmir lakes. According to author export of phosphorus and nitrogen from the catchment area, human wastes etc entering into Dal waters was estimated as 49.17 tonnes and 636.67 tonnes per annum respectively. The authors used a load tolerance model incorporating the mean depth, flushing rate and critical level of phosphorus for obtaining the degree of eutrophication.

Wanganeo and Wanganeo (1999) while studying the hydraulic detention period-carrying capacity of three valley lakes of Kashmir and the impact of flushing rate on the lake metabolism reported that the Dal lake flushes out its waters five times a year. According to these authors the flushing rate is one of the most important factors controlling lake metabolism. Kundangar and Adnan (2004) confirmed the fact in case of Nigeen lake who stated that whenever the exit gate at Nallah Amir Khan remains closed for a considerable period, numerous algal blooms and nutrient accumulation takes place.

Kundangar et al., (1995) published the hydrobiological features of Nigeen Lake during the year 1992-93, where under the authors reported the lake basin enriched to a large extent due to the sewage and effluents from the immediate Catchment. Sarwar et al., (1996) while studying the impact of floating gardens on the limnological features of Dal lake recorded higher values for conductivity, chloride, calcium, sodium, potassium, nitrate and total phosphorus near the floating gardens as compared to the open waters of the lake.

Kundangar and Sarwar (1997) published for the first time a monograph on Dal Lake on behalf of the UEED J\&K Govt. covering all aspects of Dal and Nigeen lake with particular reference to geology, morphometry, hydrology, water quality changes, biodiversity etc. Kundangar (1999) in his paper entitled, "Is Water quality at Pokhribal Nigeen fit for potable purposes?', reported that the treated lake water still had the sp. Conductivity of $985 \mu \mathrm{Scm}^{-1} @ 25^{\circ} \mathrm{C}$, Iron=346 $\mathrm{gg}^{-1}, \mathrm{NH}_{4}-\mathrm{N}=803 \mu \mathrm{gl}^{-1}$ and $\mathrm{TP}=5883 \mu \mathrm{gl}^{-1}$ which exceed the permissible limits and thus the waters are beyond permissible level. Sarwar et al., (1999) while studying the variations in the hydro biological characteristics of Nigeen Lake reported substantial contribution of diatoms to the total 
phytoplankton population. The authors also tried to draw the relation between the physio-chemical characteristics and the biological population.

The Annual Technical Reports published by J\&K lakes and waterways development authority from 1998 to 2000 resulted in generation of huge data from all the basins of Dal Lake including Nigeen. These reports chiefly deal with physico-chemical characteristics, bio-diversity changes, effluent characteristics, quantification of waste waters entering the lake basins from point and non-point sources impact assessment studies (Deweeding and dredging) and hydrological studies. According to these reports progressive increase in COD, Chlorophyll content, eutrophic algal population has been recorded at Sauderbal site in Nigeen lake.

Sameera et al., (2003) studied the impact of floating gardens on the water quality and cladocera population in Nigeen Lake. The authors reported more enrichment of waters near floating gardens as indicated by high level of chloride, phosphorus, nitrogen and electric conductivity.

Kundangar and Adnan (2004) while reviewing the ecological work carried out during last three decades on Dal Lake and comparing the past limnological data with the present recorded progressive increase in various chemical parameters viz. sp. conductivity, Total alkalinity, Sodium and potassium. A significant increase in silicate, $\mathrm{NO}_{3} \mathrm{~N}, \mathrm{NH}_{4} \mathrm{~N}$ and that of total phosphorus was also recorded. The authors recorded drastic change in lake hydrology, nutrient loads and bio-diversity.

Humaira Qadri and Yousuf (2004) studied the ecology of macrozoobenthos in Nigeen Lake reported the macrozoobenthic community influenced by the type of substarte the organic matter abundance of macrophytes as well as the concentration of calcium. The authors presented the physico-chemical features of Nigeen Lake during 2002 to record the eutrophic species.

Adnan and Kundangar (2005) studied the bacterial dynamics of Dal Lake and correlated the population density of bacteria with the physio-chemical parameters at the studied sites of Dal and Nigeen Lake. In the Nigeen lake, the high density of coliforms and faecal Coliforms was recorded at Pokhribal and Ashai Bagh by the authors. Pandit et al., (2006) studied the current limnology of Dal Lake and composing the same with the previous records reported the gradual trophic evolution of the lake eco-system as a result of mineral loading, being an outcome of growing anthropogenis pressures.
Kundangar and Adnan (2006) in a research study entitled 'limnology of Himalayan Dal lake Kashmir' compared the morphometry, hydrochemistry ionic balance, plankton flora and macrophytic vegetation of various basins of Dal Lake including Nigeen and the authors drew the comparison besides evaluating the trophic status of each basin.

Adnan and Kundangar (2009) in a research paper entitled three decades of Dal Lake pollution-restoration recorded the changes in the hydrochemistry and bio-diversity of Dal and Nigeen during the last three decades besides giving the current ecological status of Dal Lake. The authors on the basis of their investigations have proved the FAB based Sewage Treatments for treatment of effluents at Hazratbal/Habak a total failure particularly during winter months. The authors have also put forth the suggestive restoration measures for the Dal Lake eco system.

J\&K State pollution Control Board (May-July 2009) in a status report of Dal and Nigeen Lake Submitted to Hon'ble High Court of J\&K recorded the following observations: The physical condition of Nigeen when seen from Ashsi bagh bridge is visibly bad, with intense over growth of weeds and algal patches. Dense vegetation is emergent all over this area on Dal sides. Most affected areas are Bhat Mohalla, Kani Mohalla, Saida Kadal. At Kani Mohalla-Saida kadal washing of clothes in the lake periphery Is a common sight. Solid wastes too was found around on the surface of water besides large scale agricultural practices on commercial basis. The area from Ashsi-bagh bridge up to saida Kadal bridge is dotted with a number of automobile workshops on the Nigeen and Dal Lake with all wastes going to the water body.

The condition of lake near Abi-Gurpora, Jogilankar Naidyar and Gurpora-khosak is alarming. Water quality is blackish (septic in nature), turbid and murky. Effluent rich drain enters at Naidyar. In the Pokhribal water-body, the condition is equally challenging. The vital Nallah Amir Khan is choked due to wide spread emergant vegetation. The samples from the purification plant of Pokhribal on 17-07-2009, drawing water from Nigeen reveal higher content of sp-conductivity, phosphorus and nitrogen content, suggestive of tertiary treatment".

Adnan (2010) while advocating wetland treatment compartments for the waste water entering Dal Lake recorded the senative role of Phragmitis Communis, Typha augustata, Ceratophyllum demersum, Lemna sp. 
\& Salvinia natans after growing them in different fibre glass tanks containing Dal lake sediment and water. The author reported increase in $\mathrm{pH}$, creating conditions for volatilization of NH4-N, precipitation of Phosphorus and $\mathrm{CaCO} 3$ besides enhancement of dissolved oxygen, update of Nitrogen \& Phosphorus by aquatic plants thereby improving water quality.

Murtaza et al., (2010) while studying impact of pollutants on physico-chemical characteristics of the Dal Lake under temperate conditions of Kashmir on the basis of the data on physico-chemical parameters during 20072008 reported increase in sp. Conductivity, totalalkalinity, silicate and nitrate - nitrogen and decrease in dissolved oxygen content, silicate and phosphorus. The authors attributed the increase in chemical parameters to the drought condition and eutrophication while the decreases to thermal stratification and efficient utilization of these elements by macrophyte vegetation.

\section{Conclusion}

The physicochemical parameters such as $\mathrm{pH}$, colour, biochemical oxygen demand (BOD), chemical oxygen demand (COD), total suspended solids (TSS), total dissolved solids (TDS), and turbidity play an important role in determining the health of an aquatic ecosystem. Change in any of them has a profound effect on the biotic community. Hence, systematic monitoring of the lake basin and compilation of the limnological data is needed in order to establish a repository mechanism for future conservation measures.

\section{References}

Adnan Abubakr and M.R.D. Kundangar. 2005. Bacterial dynamics of Dal Lake, a Himalayan temperate freshwater lake. Nat. Env. Poll. Tech., Vol4, PP291298.

Adnan Abubakar and M.R.D. Kundangar. 2009. Three decades of Dal Lake pollution-Restoration. Eco. Env. and Cons., 15(4): PP 825-833.

Adnan Abubakar. 2010. Sanative role of Macrophytes in Aquatic Ecosystems. Nat. Env. Poll. Tech., Vol 9(4): PP 654-662.

APHA, AAWA. WPEF. 1997. Standard Methods for the Examination of water and waste water. 21st edition Washington D.C.

Ashok, K., Pandit, J.A. Javeed and Anjum Banday. 2006. Current limnology of Dal Lake in Trends In Biodiversity \& Aqua culture. edit. A. Wanganeo. Langer.
De-Terra, H. and Paterson, T.T. 1939. Studies in the iceage in India and associated human culture. Carnegie Inst. Washington, D.C.

Dianella, G. 1992. Studies sul Glaciale sped. Ital de fillipi. Res. Sci., 3.

Drew, F. 1875. The Jammu and Kashmir territories London.

Edmonson, W.T. and Hutchinson, G.E. 1939. Report on Rolatoria. Mem.Conn. Acad., 10: 153-186.

Enex. 1978. Pollution of Dal lake. Enex of New Zeland inc.

Golter, C.R., and Clymo, R.S. 1969. Method for chemical analysis for fresh waters. IBP Handbook. Blackwell Scientific Pub. Oxford.

Gupta, P.K. 2004. Methods in environmental analysis Agrobios (India) Jodhpur.

Hassan, G.S. 1885. Tarikhi-Hassan Vol.1 Directorate of Research and Publications Srinagar, Rep.

Humaria Qadri and A.R. Yousf. 2004. Macro zoobenthos in Nigeen Lake. Jr. Res \& Dev., Vol 4. CORD, Univ. of Kashmir.

Kachroo and B.L. Suri. 1987. A decade of pollution in Dal Lake Kashmir. Acad. Env. Biol., AEB and Symp.

Kango, R.A., Dubey, K.P Zutshi, D.P. 1987. Sediment chemistry of Kashmir Himalayan Lake. Clay Mineralogy chemical. Geol., 64: 121-126.

Kant, Shahsi and P. Kachroo. 1977. Limnological studies in Kashmir lakes. Hydrobiological features, composition and periodicity of phytoplankton in the Dal and Nigeen lakes Phykos, 16: 77-97.

Kaul, V., Trisal, C.L. and Kaul, S. 1980. Mineral removal potential of some macrophytes in two lakes of Kashmir. J. Ind. Bot. Soc., 59: 108-118

Kundangar, M.R.D. 1973. Limnological data of Dal and Nigeen lake during 1971-1972 (unpublished.

Kundangar, M.R.D., S.G. Sarwar and M.A. Shah. 1995. Hydro biological features of Nigeen lake 19921993. tech report no 3(B) Hydrobiology Res.lab S.P. College Sgr.

Kundangar, M.R.D. and S.G. Sarwar. 1997. A monograph on Dal Lake UEED J\&K Govt.

Kundangar, M.R.D. 1999. "Is water quality at pokhribalnigeen fit for potable purposes"? 5th. Nat. seminar on fish \& their env. abst) P.G. Dept. of zoology Univ. of Kashmir.

Kundangar, M.R.D. and Adnan Abubakar. 2004. Thirty years of ecological Research on Dal Lake Kashmir. Jr. Res and Dev., Vol. 4. Univ. of Kashmir.

Kundangar, M.R.D. and Adnan Abubakar. 2006. Comprative limnology of Himalayan Dal Lake Kashmir in Wanganeo and R.K. Langer Ed. Trends 
of biodiversity and aqua culture . Daya publishing House, Delhi.

Lawrence, R.W. 1895. The valley of Kashmir Oxford university Press.

Mackereth, F.J.H. 1963. Water analysis for limnologist. Fresh Water Biol. Assoc., 21: 70 pp.

Murtaza, S., M.A. Aziz, S.M. Fazshi Ah. and S.A. Hassan. 2010. Physico-chemical characteristics of Dal Lake water, temperate Conditions of Kashmir.

Sameera Siraj, A.R. Yousuf and Muni Parveen. 2003. Impact of floating gardens on the water quality and Cladocera population. Jr. Res and Dev. Vol 4 Univ. of Kashmir.

Sarwar, S.G. A.R. Naqashi and G.R. Mir. 1996. Impact of floating gardens on the limnological features of Dal Lake poll. Res., 15(3): 217-221.

Sarwar, S.G. M.A. Shah and P.A. Raashid. 1999. Variations in the hydro biological characteristics of Nigeen Lake. Fifth national Seminar on fish and their environment.(Abst) P.G. Deptt. Of Zoology Univ. Of Kashmir.

Trisal, C.L. 1987. Ecology and Conservation of Dal Lake Kashmir. Butterworth and Co. Pub.co.

Urfi, S. 1985. Physical, chemical and trace metal analysis of Dal Lake. M.Phill dissertation, Univ. Of Kmr.
Vass, K.K., Zutshi, D.P. 1979. Limnological studies on Dal Lake. Morphometry and Physical features. $J$. Ind. fish. Soc. India, (11): 12-20.

Vass, K.K., Zutshi, D.P. 1983. Energy flow, trophic evolution and ecosystem management of a Kashmir Himalayan Lake Arch. Hydrobiol., 9: 39-59.

Wadia, D.N. 1947. Geology of India Mc Millan,U.K.

Wanganeo, A.R., Wanganeo. 1994. Hydraulic detention period carrying capacity of a system, J. Hydrobiol., 10(1): 1-6.

Zutshi, D.P. 1968. Ecology of some Kashmir lakes Ph.D. Thesis J\&K university (unpublished).

Zutshi, D.P. and Vass, K.K. 1973. Variation in water quality of some Kashmir lakes. Trop. Ecol., 14: 182-196.

Zutshi, D.P. and Khan, M.A. 1978. On lake topology of Kashmir. Env. Physiol. Ecol. Plants, 465-472.

Zutshi, D.P. and M.R.D. Kundangar. 1983. Modification In physical and chemical environment of Dal Lake national workshop on conservation of Dal lake. Octr.15-17 (Abst) CORD Univ. Of Kashmir.

Zutshi, D.P. and A. Wanganeo. 1988. Nutrient dynamics and trophic statues of Kashmir lakes, Ind.Sci Congr. Jubilee Session Pune.

\section{How to cite this article:}

Shariqa Maryam. 2017. A Review on Monitoring Water Quality in Dal Lake. Int.J.Curr.Res.Aca.Rev. 5(3), 43-47. doi: https://doi.org/10.20546/ijcrar.2017.503.007 